\title{
Halina Święczkowska
}

University of Bialystok

Beata Piecychna*

University of Bialystok

\section{LANGUAGE ACQUISITION IN THE LIGHT OF RATIONALIST PHILOSOPHY OF MIND AND PHILOSOPHY OF LANGUAGE}

\begin{abstract}
The present study deals with the problem of the acquisition of language in children in the light of rationalist philosophy of mind and philosophy of language. The main objective of the paper is to present the way Gerauld de Cordemoy's views on the nature of language, including its socio-linguistic aspects, and on the process of speech acquisition in children are reflected in contemporary writings on how people communicate with each other. Reflections on 17th-century rationalist philosophy of mind and the latest research conducted within the field of cognitive abilities of human beings indicate that between those two spheres many similarities could be discerned in terms of particular stages of the development of speech and its physical aspects.
\end{abstract}

Keywords: philosophy of mind, philosophy of language, human communication, language acquisition.

Much work within the area of linguistics has been devoted to the problem of language acquisition. Reflections upon the nature of language as well as the way human beings acquire it have been central to the study of communication. Despite an increasing interest in the ability of man to acquire language, still little is known about fundamental questions concerning language development in children. In addition, in spite of the fact that investigators are aware of the fact that the child usually learns to speak according to some general parameters of order and sequence, there is no consensus among scientists as to the exact way the process takes place. Several attempts have been made to explain this process; however, it is still shrouded in mystery. An accurate description of the nature of the phenomenon was provided by O'Grady (2005: 1): 
Most of the time we adults take language for granted - unless of course we have to learn a new one. Then, things change pretty quickly. We can't get the pronunciation right, and we can't hear the difference between sounds. There are too many new words, and we forget ones that we learned just the day before. We can't say what we want to say, and we can't understand anything either, because everyone speaks too fast.

Then, as if that isn't bad enough, we come across a three-year-old child and watch in envy and amazement as she talks away effortlessly in that impossible language. She can't tie a knot, jump rope, draw a decent-looking circle, or eat without making a mess. But while she was still in diapers, she figured out what several thousand words mean, how they are pronounced, and how they can be put together to make sentences.

Investigating the way children acquire language is a continuing concern within applied linguistics. A comprehensive text was written by Lust (2006), who discussed the notion in terms of the latest achievements in not only linguistics but also in psychology and in cognitive science. A recent study by Allott (2012) involved the problem of language acquisition in children as juxtaposed against the backdrop of the motor theory. It is also worth mentioning de Boysson-Bardies (2001: 1), who considers a natural tendency to acquire languages "a gift inscribed in the generic inheritance that is ours by virtue of human beings." In addition, over the past years there has been a dramatic increase in textbooks on language acquisition in children (Elliot 1981, Ingram 1989, Peccei 2006, Saxton 2010, Clark 2016).

There are three main disciplines which are concerned with these complex theoretical issues, namely, linguistics, psychology and philosophy of language. Linguists are interested in the way language acquisition as a linguistic process is organised; much attention is devoted to how certain units of language (phonemes, morphemes, phrasemes etc.), and in which order, are connected in order to produce meaningful pieces of information. In addition, linguists underline the key role that the knowledge of individual speakers performs in the process of language development. A key aspect of a linguistic perspective from which language acquisition is analysed is also so-called language commonalities. As Barry (2002: 4-5) claims, these are "more general and abstract principles of language structure and organization that apply to all languages." The notion plays an important role in the discussion of the nature of human language because "the more we learn about the commonalities among languages, the more we understand how human beings organize (and do not organize) language information in their minds and call it into use to serve their needs" (ibid). Central to the entire field of language acquisition is also the concept of second language 
acquisition; the issue has received considerable critical attention (see Slabakova 2016).

Language acquisition in children is also a major area of interest within the field of psychology. Publications such as those written by Mukalel (1998) or by Dörnyei (2009) show the importance of taking into consideration the results of studies conducted within the following fields of research: cognitive linguistics, psycholinguistics, neurolinguistics, cognitive neuroscience, and cognitive science. In addition, recently investigators have examined the relationship between language and the brain, implicit versus explicit learning as well as connectionist approaches (see Schütze 2017). There is also a large volume of published studies describing the role of evolution of mind and brain in the process of language development (see Bolhuis \& Everaert 2013).

The issue of the way a language is acquired has also received considerable critical attention among philosophers. It is beyond the scope of this paper to refer to all possible philosophical interpretations of this problem; therefore, let us only refer here to Gadamer's way of seeing how language is bound together with the world that surrounds us as well as with our thinking system. By drawing on the concept of the interrelation between these three spheres, Gadamer was able to show that "in all our knowledge of ourselves and in all knowledge of the world, we are always already encompassed by language" (1976: 63). This reflection bears resemblance to the main tenets of cognitivism, according to which language should be perceived as a social, historical and cultural phenomenon, and not as a specific tool by means of which it is possible to communicate with one another, because "language is the fundamental mode of operation of our being-in-the world and the all-embracing form of the constitution of the world" (3). As indicated, it is beyond the scope of the article to refer in detail to the ideas of language acquisition suggested by various philosophers; however, what is crucial at this point is that philosophical reflections upon the nature of language often resonate with contemporary writings on the relationship between language and human cognition. The evidence for this is reviewed in the paper. The remaining part of the article presents an occasionalistic interpretation of human speech by de Cordemoy and the way it is now reflected in the contemporary writings on human cognition.

$$
* \quad *
$$

As a Cartesian by belief and an occasionalist and atomist by conviction, de Cordemoy was not a leading figure in occasionally oriented rationalist philosophy. Philosophical works from that period either do not mention him 
at all or write only one sentence about him. The philosopher has gained a little fame in modern times thanks to his work A Philosophical Discourse Concerning Speech, which placed him in the Cartesian philosophy of language, according to N. Chomsky (1966).

The main objective of $A$ Philosophical Discourse Concerning Speech is to illustrate the relationship between the acoustic nature of language and the meaning contained in it. The analogy between the physical aspect of speech and its semantic dimension and the relationship between the body and soul seems obvious, and de Cordemoy establishes his arguments upon it, additionally enforcing the theory with occasional causation.

The starting point for his consideration is the assumption of the existence of bodies which produce sounds. Cordemoy completely adopts the Cartesian point of view, arguing that even though there are natural beings other than humans capable of producing sounds, these do not have that significant dimension which characterises the sounds produced by humans. Human language is the only one which refers directly to thoughts, proving that humans are the only thinking beings. Similarly to Descartes, the philosopher also considers physiological reasons, admitting that despite the fact that animals are capable of imitating human speech, they lack any linguistic competence, and he concludes that the lack of language in animals is a consequence of their utter lack of thought (Kopania 1993: 14).

This "language" argumentation - clearly Cartesian - is reinforced by de Cordemoy with comments which do not appear explicitly in Descartes. The philosopher states that speaking is nothing more than explanations of thoughts to those who are able to understand them, and the only means of explaining to each other what we are thinking is the communication of external signs (Cordemoy 1668: 36). The fact that humans use sounds in this manner proves the existence of man's soul. Cordemoy finds evidence for his own soul by internal experience, while the souls of others are confirmed by the existence of bodies producing sounds which answer to my signes by other signes, which give me images agreeable to what I think (...) (36).

Sound has its own physical dimension, but thanks to its significance it also gains a spiritual aspect, as it allows the indicating of the "inspiration of thoughts in the soul". This relationship between the material form of a song and its meaning is explained by de Cordemoy in a purely occasionalistic way. He claims that the Author of Nature, in forming a Man, so well unites some Thoughts of his Soul to some motions of his Body, that those motions cannot be raised in the Body, but the thoughts must also be forthwith excited in the Soul (44-45). He also proves that the necessary relationship formed between the body and the soul implies also a need for creating signs used 
to transfer thoughts. A soul cannot possess thoughts that would not create some movement in the body. Therefore, the only efficient cause of human communication is God, who presides over the fact that two Souls untied to two different Bodies do express their thoughts by Motions, or, if you will, by outward Signs (ibid).

The occasionalistic interpretation of human speech presented by Cordemoy is entirely supported by both its historical and philosophical background. In Hegelian terms, the philosopher could not escape history. Still, if we set aside the speculative sphere of his Discourse, we will be able to find in it the theses that are presented with astonishing insight, given the times in which they were written.

The philosopher openly assumes two theses that outline the Cartesian concept of language: the thesis on the significant dependence of language and thought, and the thesis about the conventionality of language. The first thesis is a direct consequence of the assumption that the reality inside the mind is only the primary cognitive reality of man. It implies the necessity of assuming that works refer directly to thoughts (more precisely, ideas), resulting in the conclusion that only thinking beings are capable of using language. The second thesis is the consequence of the fact that one and the same structure of thoughts in all humans is expressed in different languages (Kopania 1996: 28 and ff). Cordemoy explains the conventional character of the linguistic sign by referring to the agreement concluded between people upon which signs or sounds get their meaning. What is more, he claims that those same signes are the only means to entertain Society amongst Men, which is the greatest good, they have in this World (Cordemoy 1668: 42-43). It is impossible to find such ideas concerning society creating the function of language in the traditional rationalism of the $17^{\text {th }}$ century, although it was present in empirically-oriented philosophy.

Cordemoy discerns two types of signs. The first are natural signs, such as facial expressions, looks, gestures, or cries, used to express various emotional states. It is, in his words, the most natural way to express our thoughts, it is also the first of all the Languages, and the most Universal that is in the World, since there is no Nation, but understands it (47). Still de Cordemoy believes that since humans through some form of exercise are able to master their emotions, emotions cannot be fully trusted, as they can be misleading. This language of the body can also be seen in animals, although it has no significant character, since an animal's cry is only caused, according to Cordemoy, by movement in the brain (75). The second type of signs are normal signs, originating only in institution. Among these, Cordemoy lists those signs that are elements of language, and those which are 
extralingual but have significance, such as the nod of a head upon greeting. The philosopher highlights that the significance of these last signs is a result of the conventions in a particular country (101). It is also possible to use signs, called special signs by de Cordemoy, comprising some private languages. Voice itself also has a significant character. Even though voice is a gift of nature, the philosopher believes that its sound, which can be modulated, may mislead the listener (104). This seemingly minor remark is rather significant because the first work in linguistic literature known for its approach to the human voice is an article by E. Sapir, Speech as a personality trait (1978).

Apart from the clearly sociolinguistic themes of the Discourse, there is another theme which has a psycholinguistic character. One of the astonishingly interesting issues touched upon by de Cordemoy is the way children acquire language. He devotes a separate part of his deliberations to this issue, and contains it in two fragments of the Discourse: the way children learn to speak and how grammarians imitate this. Although the author's remarks, seen from today's perspective on language acquisition, may seem obvious and superficial, when they are placed in the historical context of the $17^{\text {th }}$ century level of knowledge of children's developmental psychology, they become innovative and simply revolutionary. The Discourse is one of the few texts of its time, if not the only one, whose author concentrates on the cognitive mechanisms of early childhood, and his approach to children is far from the social and cultural standards of the epoch.

The uniqueness of de Cordemoy's arguments becomes evident in the context of P. Ariès's monograph, Centuries of Childhood, where the author argues about the historical shift of the concept of the child and childhood, which is not a natural biological form, but rather a recent social construct. The Middle Ages knew neither childhood nor youth, as family life as it is understood today appeared only in later centuries. Ariès indicates that each epoch had a specific prioricity of life and single privileged period. In the $17^{\text {th }}$ century it was "youth" while in the $19^{\text {th }}$ century it was "childhood". The attitude to this age was defined by demography. The lack of young age and disregard for old age, or on the contrary - the disappearance of old age and the appearance of youth - was a social reaction to the average lifespan of people (Sapir 1978: 55).

The significance of the $17^{\text {th }}$ century in the evolution of the subject of early childhood is seen most prominently in iconography and painting, in Ruben's family portrait, in genre art by Hals, van Dyck, or Lebrun (47). A new attitude towards children is also confirmed by new terminology originating in the $17^{\text {th }}$ century. The range of meanings of the word child 
in the French language was very broad until the end of the $16^{\text {th }}$ century, but also in the $17^{\text {th }}$ century. According to the life period calendar from the $16^{\text {th }}$ century, a child is strong and virtuous when it is twenty-four years old (22). Such length of childhood was the result of complete indifference to purely biological phenomena. The idea of childhood was closely connected with the ideas of senior or feudal relations. Childhood ended when a person became free from others, at least those below him (ibid).

Terminology connected with childhood develops and acquires more modern meaning in Port-Royal and its ethical and poetical literature. Jacqueline Pascal's pupils are divided into "small", "medium", and "big". However, the French language of the $17^{\text {th }}$ century, when used to discuss small children, was limited by its lack of proper terminology. The situation was similar with the English language, where the word baby also referred to older children. French was therefore forced to borrow words from other languages or use dialects. Hence, next to the Italian word bambin, the language adopted also the Provencal word pitchoun or the Latin populo (small person). These words refer to small children who can make contact with those surroundings, three or four year olds. Still, there is no word to describe an infant. Only in the $19^{\text {th }}$ century, the word bébé, from the English word baby, filled this gap and - in Ariés's words - the infant finally had a name (25-29).

This staggering ignorance and indifference towards the child and childhood from the Middle Ages to the $17^{\text {th }}$ century, supported by Ariès with numerous examples from source documents, sacral art, literature, iconography and painting, can only be comprehended in the context of staggering infant and child mortality, reaching as high as tens of percentage points (43).

The end of the $17^{\text {th }}$ century also revealed a new approach to the child in view of its further development. In the Rules for educating children from 1687 we read that: [people] need to love children and to overcome the repugnance which they arouse in thinking men: If one considers the child's exterior, which is nothing but weakness and infirmity of either body or mind, [...] But one changes one's opinion if one looks into the future and acts in the light of Faith. Beyond the child one will then be able to see 'the good magistrate', 'the good priest', 'the great lord' (ibid). This is a great shift as due to the high mortality, children did not use to be seen as future adults, as they are perceived now $(64)^{1}$.

When describing the mechanism of language acquisition in children, de Cordemoy puts it in the context of his previous deliberations on the way adults learn second languages and argues that learning languages is simple, since newborn children do it when they learn their native tongue. The philosopher highlights the fact that children are born with a reper- 
toire of behaviours necessary to show emotional states - signs shown in body language. These signs are shared by all humans and are expressed and recognised by children in "natural signs" observed in adults. Cordemoy writes, (...) and how little time so ever they have lived, they so well study the looks of their Nurse, that she can make them weep or laugh, by only looking on them. Thus they easily know the passions of those that come near them, by the external motions, which are natural signes of them (Cordemoy 1668: $51-52)$.

The next step of linguistic development is the ability to recognise the conventional nature of the linguistic sign. It is accompanied, according to de Cordemoy, with focus, an ability which is necessary to associate names (sounds) with things using ostensive definitions. It is true, that ordinarily we endeavour to excite in them some passion (as joy) by some cry, which accompanying the shew that is made to them of the things at the same time, when we tell them their names, maketh that they are more attentive to them, and by being more affected with them by this means, they retain them the better (52).

The philosopher believes, however, that irrespective of the efforts that adults put into teaching children a language, children will naturally learn the names of thousands of different things that were not intended to be shown to them. What is most surprising to the author is the fact that 2 3 year olds are able to find the name of an object in all contexts in which it was mentioned $(52-53)$.

The order of acquiring linguistic competence is based on, according to de Cordemoy, a child's natural cognitive order. So, he notes, a child first learns the names of objects and recognizes their designates through words. Therefore, the first words that appear are nouns. He goes on to write that it can be observed that children do not pay attention to words describing the actions of objects unless they first learn its name or the name of qualities which make the object appeal to the child. This means that in this cognitive order, the next stage of linguistic development is the ability to recognize and acquire qualitative descriptions, namely, adjectives.

Cordemoy also makes interesting remarks on children learning action words, whose meanings are recognized in specific social cooperation. The initiation of this process requires an active caretaker who would name specific actions and carry them out together with the child repeatedly.

Identification of the mechanisms of learning adverbs, quantifiers, conjunctions, and particles is far more difficult. Cordemoy writes that children learn this vocabulary at a significantly later time, and the necessity of learning nouns, adjectives, and verbs is a result of the child's life needs, which 
can be described as the preliminary development phase of linguistic competence, allowing them to form communicative bonds with those environment so that the child can carry out its plans or actions (56-58).

Cordemoy also indicated another, sentence-oriented stage of linguistic development. It is the moment when a child, when it wants to express an action, places the word which indicates the action next to the name of an object. Although, he notes, the child does not use tense differentiation and ignores conjugation, the child has finally mastered grammar, according to the philosopher - thanks to the natural cognitive order.

This analytical approach to his study of the mechanism of language acquisition is connected by the philosopher with an assumption of the intellectual potential of humans at an early stage of development. Cordemoy writes that he desire only, that by the way an important truth may be taken notice of, which this example of children evidently discovers to us, viz. That from their birth they have their reason entire, because indeed this way of learning to speak is the effect of so great a discerning, and of so perfect reason, that a more wonderful one cannot possibly be conceived (59). It is impossible to find such clear conviction about the cognitive abilities of children from birth in $17^{\text {th }}$ century literature, neither philosophical nor pedagogical.

Cordemoy also supports this claim in a different context, namely in the context of possessing knowledge. He notes that although it seems that children act, in later years, as if they had almost no reason, it is not necessarily so and it is only the result of inadequate experience and knowledge. The final confirmation of its reason is the fascinating skill of learning language, in an astonishingly short time, unavailable for adults. Although Cordemoy's views do not go far off from the views of Descartes (2006: 137), the latter philosopher wrote very briefly on children's cognitive abilities, and only when discussing other issues, assuming, for example, that the power or reason in infants is dormant ${ }^{2}$. Therefore, it can be argued that Cordemoy's position, when compared to the views of his contemporaries, is definitely sharp and radical.

It is worth noting that de Cordemoy had perfect conditions for making direct observations on the linguistic behaviour of children and infants, unlike Descartes or Leibniz, as he fathered five children - four sons and a daughter. Although the Discourse does not contain any direct references to the sphere of parental experience, the examples that the author provides, mainly in terms of learning action phrases, can arise from his personal involvement in forming his children's development.

It must be stressed that Discourse, in the section on the mechanisms of language acquisition, is a unique document for its time, in which the 
author reveals his set of claims on the intellectual potential of children. His claims are also extremely interesting in the context of modern studies on the development of linguistic competences of children.

The area of these studies is not only empirical, as it also requires researchers to assume significant philosophical theories on language itself, as the nature of linguistic competence in connection with the phenomenon of the human mind still is not only a sphere of scientific theory. This is so in the sphere of studies placed in empirical theory (Skinner, Quine) but also in the case of research referring to rationalism, represented by Chomsky or Pinker. The works of these two scholars fit perfectly with what may be called the Cartesian perception of language, although Chomsky's theory about the existence of a specialised grammatical module in the brain, called the Language Acquisition Device, with which small children are able to quickly acquire the complex grammars of numerous languages, surely cannot be devised from de Cordemoy's claims on language (Chomsky 1990).

Doubtlessly, de Cordemoy assumes the existence of an innate cognitive mechanism that is responsible for language acquisition. Yet, in his deliberations on the stages of language development in children there is not a single sentence that would substantiate the existence of a universal grammar, and the only assumption that is clearly argued is one about the possession of reason. In his description, language is shaped by the social interaction of the child and the world from the moment of its birth. This aspect of linguistic activity is presented in the German psychologist M. Tomasello's works. If Tomasello in some way belongs to a tradition that can be called rationalist, it is expressed by the evolutionary claim that humans have a biologically inherited ability to live in culture. This ability is characterised as the ability to understand specimens of the same species as intentional beings that use reason "as I do" (Tomasello 2000).

This is not to say that in his studies on speech development in children de Cordemoy anticipated the scientific assumptions accepted today, but his intuition was very close to the evidence presented by Tomasello and researchers quoted by him. Tomasello writes that from birth, if not earlier, infants are social, or even "ultrasocial" beings. Shortly after birth, infants engage in "protoconversations" with their caretakers. Some researchers believe that these protoconversations are intersubjective. Even if this is not true, these early interactions are extremely social because of their emotional charge and alternating structure. Therefore, within early social interactions, infants recreate some movements of the adult's bodies, especially the movements of the mouth and head (Tomasello 2000: 81). As indicated above, Cordemoy thought so too. 
Further development stages of children's communicative abilities analysed by Tomasello refer to the ability to express their own emotions and identify these emotions in adults in alternating sequences. Additionally, at approximately 9-12 months of age, children start to exhibit another type of behaviour. They become trilateral, meaning that they involve coordinated interactions between people and objects. It is precisely at this age when an infant starts to adjust itself to the behaviour of adults, directing their attention to external objects. Tomasello explicitly names it the cognitive revolution of the ninth month.

Tomasello claims that at the age of 9 months, children become ready for completely new ways of participating in the world of culture. This is possible through the new understanding of other people as intentional causes of activities affecting external objects. Children begin to learn to have an impact on the world by imitating the behaviour of adults (105). These extralingual communicative behaviours, which require mutual attention and the ability to identify the intentional actions of adults, precede the ability to identify the symbolic representations and communicative intentions of adults. Tomasello describes this process very broadly. What is noteworthy, similarly to de Cordemoy, he indicates a pre-sentence stage of shaping the linguistic abilities of children, a stage called by him holophrasis, and finally, the ability to use complex syntactical structures.

What is most astonishing is the fact that despite an increasing number of studies and works published in this field, the language acquisition mechanism itself is still shrouded in mystery, as seen in Tomasello's remarks, which are completely correspondent with what can be found in the Discourse. Still nothing is known about how children learn conjunctions, particles, and all the other "small words" which allow them to build complex narratives (138). In this context, the insight and scientific intuition expressed by the author of the Discourse about children's language acquisition must be highlighted, although it was underestimated by his fellow Cartesian continuators and philosophers of language.

The issues presented here do not fully expand on all of the problems touched upon by the philosopher. Cordemoy devotes a lot of space to the description of the physical aspects of speech. This description is purely mechanical and has nothing that would go outside the Cartesian methodology of scientific proof. The process of speaking is boiled down to the physiology of sound production where the explaining principle is - to use modern terminology - a behaviourally perceived reaction to stimuli. The mechanical description of sound production leads him to a presentation of the phonetic characteristics of vowels and consonants. In the Discourse, the author 
touches upon many themes connected with broadly perceived human communication, deliberating on eloquence, lie, or truthfulness. The Discourse is, in a sense, a document of its time. It is also, as I have tried to show, a work that proves the great scientific intuition of the author, who was one of the pioneers to try to outline the intellectual development of humans in the context of linguistic communication.

\section{N O T E S}

* The first part of the paper, devoted to the introduction to language acquisition, was written by Beata Piecychna, while the remaining part by Halina Święczkowska.

1 Cf. Wyczański, A. (2001). Szlachta polska XVI wieku. Warszawa, PWN, p. 36; Kuklo, C. (2009). Demografia Rzeczypospolitej Przedrozbiorowej. DiG, Warszawa, p. 404. Kamler, A. (2006). Od szkoly do senatu. Wyksztalcenie senatorów w Koronie w latach 15001-1586, Studia, Warszawa, p. 43.

2 More deliberations on the relation between infants and reason may be found in such Descartes' works as Passions of Soul, Discourse on the Method, or Principles of Philosophy.

\section{R E F E R E N C E S}

Allott, R. (2012). The Child and the World: How the Child Acquires Language; How Language Mirrors the World. Xlibris, Bloomington.

Ariès, P. (1962). Centuries of Childhood. A Social History of Family Life. Random House, New York.

Barry, A. K. (2002). Linguistic Perspectives on Language and Education. Bergin \& Garvey, Westport-London.

Bolhuis, J. J., Everaert, M. (eds.) (2013). Birdsong, Speech, and Language: Exploring the Evolution of Mind and Brain. The MIT Press, Cambridge-London.

Boysson-Bardies, B. de (2001). How Language Comes to Children: From Birth to Two Years. The MIT Press, Cambridge-London.

Chomsky, N. (1966). Cartesian Linguistics. Harper\&Row, New York-London.

Chomsky, N. (1990). On the Nature, Use and Acquisition of Language. In W. G. Lycan (ed.) Mind and Cognition. Blackwell, Oxford-Cambridge.

Clark, E. V.(2016). First Language Acquisition. Cambridge University Press, New York.

Cordemoy, G. de (1668). A Philosophical Discourse Concerning Speech. London.

Descartes, R. (2006). Meditations, Objections, and Replies. Ed. by R. Ariew, Indianapolis.

Dörnyei, Z. (2009). The Psychology of Second Language Acquisition. Oxford University Press, Oxford. 
Language Acquisition in the Light of Rationalist Philosophy of Mind...

Elliot, A. J. (1981). Child Language. Cambridge University Press: New York.

Gadamer, H.-G. (1976). Philosophical Hermeneutics. University of California Press, Berkeley-Los Angeles.

Ingram, D. (1989). First Language Acquisition: Method, Description, and Explanation. Cambridge University Press: New York.

Kamler, A. (2006). Od szkoły do senatu. Wykształcenie senatorów w Koronie w latach 1501-1586, Studia, Warszawa.

Kopania, J. (1996). Descartes'a refleksje nad jezykiem. In J. Kopania, Descartes i Kant o użyteczności poznawczej języka naturalnego. Biblioteka Myśli Semiotycznej, Warszawa.

Kopania, J. (1993). Wstep. In G. de Cordemoy (1993). Rozprawa fizykalna o mowie, transl. by J. Kopania, B. Głowacka, Zakład Semiotyki Logicznej Uniwersytetu Warszawskiego, Warszawa.

Kuklo, C. (2009). Demografia Rzeczypospolitej Przedrozbiorowej. DiG, Warszawa.

Lust, B. (2006). Child Language: Acquisition and Growth. Cambridge University Press, Cambridge.

Mukalel, J. C. (1998). Psychology of Language Learning. Discovery Publishing House, New Delhi.

O'Grady, W. (2005). How Children Learn Language. Cambridge University Press, New York.

Peccei, J. S. (2006). Child Language: A Resource Book for Students. Routledge, London-New York.

Sapir, E. (1978). Mowa jako rys osobowości. In E. Sapir. Kultura, język, osobowość. Państwowy Instytut Wydawniczy, Warszawa.

Saxton, M. (2010). Child Language: Acquisition and Development. Sage Publications Ltd, London.

Schütze, U. (2017). Language Learning and the Brain: Lexical Processing in Second Language Acquisition. Cambridge University Press, Cambridge.

Slabakowa, R. (2016). Second Language Acquisition. Oxford University Press, New York.

Tomasello, M. (2000). The Cultural Origins of Human Cognition. Harvard University Press, Cambridge-London.

Wyczański, A. (2001). Szlachta polska XVI wieku. Warszawa, PWN. 